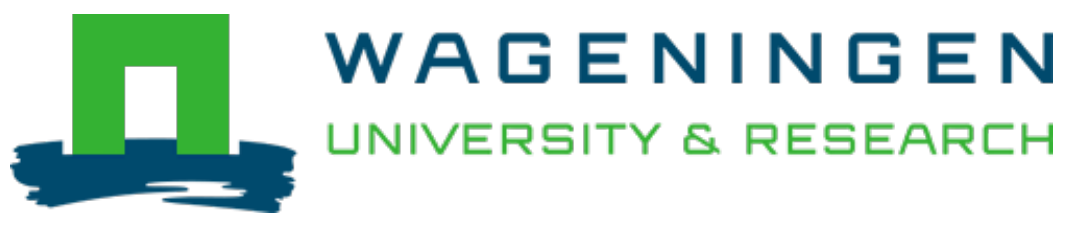

\title{
Iron, zinc and phytic acid content of selected rice varieties from China
}

\author{
Journal of the Science of Food and Agriculture
}

Liang, J.; Han, B.Z.; Han, L.; Nout, M.J.R.; Hamer, R.J.

https://doi.org/10.1002/jsfa.2747

This publication is made publicly available in the institutional repository of Wageningen University and Research, under the terms of article $25 \mathrm{fa}$ of the Dutch Copyright Act, also known as the Amendment Taverne. This has been done with explicit consent by the author.

Article $25 \mathrm{fa}$ states that the author of a short scientific work funded either wholly or partially by Dutch public funds is entitled to make that work publicly available for no consideration following a reasonable period of time after the work was first published, provided that clear reference is made to the source of the first publication of the work.

This publication is distributed under The Association of Universities in the Netherlands (VSNU) 'Article $25 \mathrm{fa}$ implementation' project. In this project research outputs of researchers employed by Dutch Universities that comply with the legal requirements of Article $25 \mathrm{fa}$ of the Dutch Copyright Act are distributed online and free of cost or other barriers in institutional repositories. Research outputs are distributed six months after their first online publication in the original published version and with proper attribution to the source of the original publication.

You are permitted to download and use the publication for personal purposes. All rights remain with the author(s) and / or copyright owner(s) of this work. Any use of the publication or parts of it other than authorised under article $25 \mathrm{fa}$ of the Dutch Copyright act is prohibited. Wageningen University \& Research and the author(s) of this publication shall not be held responsible or liable for any damages resulting from your (re)use of this publication.

For questions regarding the public availability of this publication please contact openscience.library@wur.nl 


\title{
Iron, zinc and phytic acid content of selected rice varieties from China
}

\author{
Jianfen Liang, ${ }^{1,3}$ Bei-Zhong Han, ${ }^{1}$ Longzhi Han, ${ }^{2}$ MJ Robert Nout ${ }^{3 *}$ and \\ Robert J Hamer ${ }^{3}$ \\ ${ }^{1}$ College of Food Science and Nutritional Engineering, China Agricultural University, Beijing 100083, P.R. China \\ ${ }^{2}$ Institute of Crop Science, Chinese Academy of Agricultural Sciences - NFCRI, Beijing 100081, P.R. China \\ ${ }^{3}$ Department of Agrotechnology and Food Sciences, Wageningen University, Wageningen, the Netherlands
}

\begin{abstract}
Rice is the major Chinese staple food (per capita approx $250 \mathrm{~g} \mathrm{day}^{-1}$ ) and, as such, is an important source of essential minerals. However, due to a number of factors the bio-availability of these minerals is limited. In this study, the variation of phytic acid (PA), iron (Fe) and zinc $(\mathrm{Zn})$ levels in 56 varieties of Chinese rice was investigated. The samples included in this study were collected in proportion to the importance of the rice-growing regions in China. Fe levels showed the biggest variation $\left(9-45 \mathrm{mg} \mathrm{kg}^{-1}\right)$ and were not related with PA content or grain shape although growing locations were identified yielding higher $\left(25.2 \mathrm{mg} \mathrm{kg}^{-1}\right)$ and lower $\left(14.2 \mathrm{mg} \mathrm{kg}^{-1}\right) \mathrm{Fe}$ levels. Zn showed a moderate variability $\left(13-39 \mathrm{mg} \mathrm{kg}^{-1}\right)$, which was narrower than for Fe, while broader than for PA $\left(7.2-11.9 \mathrm{~g} \mathrm{~kg}^{-1}\right)$. Zn content is correlated $\left(R^{2}=0.5 ; P<0.01\right)$ with PA content, and shows a relation with growing region and kernel shape. Variation of PA content is the least among the three components. Molar ratios of PA to Fe and $\mathrm{Zn}$ ranged from 15 to 105 and 27 to 67, respectively. The results of the mineral contents and PA content can be interpreted in terms of expected bio-availability. This study shows that the mineral bio-availability of Chinese rice varieties will be $<4 \%$. Despite the variation in mineral contents, in all cases the PA present is expected to render most mineral present unavailable. We conclude that there is scope for optimisation of mineral contents of rice by matching suitable varieties and growing regions, and that rice products require processing that retains minerals but results in thorough dephytinisation.
\end{abstract}

(c) 2006 Society of Chemical Industry

Keywords: rice; iron; zinc; phytic acid; varieties

\section{INTRODUCTION}

Rice is the primary food source for more than half of the world population. In Asia, it serves as the major source of energy, protein, thiamine, riboflavin, niacin, iron $(\mathrm{Fe})$ and calcium $(\mathrm{Ca})$ in the diet. ${ }^{1}$

Rice is also the most important staple food in China. In 2004 , the national production was estimated at 18.7 million tons, ${ }^{2}$ with a per capita consumption of $251 \mathrm{~g} \mathrm{day}^{-1}$. This accounts for $30.4 \%$ of the supply of dietary energy, $19.5 \%$ of dietary protein, and $2.5 \%$ of dietary fat. ${ }^{3}$ Rice is also the major source of intake of micro-nutrients such as zinc $(\mathrm{Zn})$, iron, and vitamins for the Chinese, especially those who live in the southern countryside.

Unfortunately, rice does not supply minerals adequately. It only has limited contents of $\mathrm{Fe}$ and $\mathrm{Zn}$, and moreover the loss of minerals, particularly of $\mathrm{Fe}$, during rice milling is high. ${ }^{4}$ In addition, rice contains phytic acid (PA), the most important anti-nutritional factor impeding availability of divalent minerals. It forms complexes with mineral ions, such as $\mathrm{Fe}, \mathrm{Zn}$ and $\mathrm{Ca}$, and ultimately affects their bio-availability. ${ }^{5-7}$

The bio-availability of minerals in rice could be improved by the selection of varieties with a high mineral content suitable for certain growing regions, by using plant breeding for high mineral content or low PA content, or by processing methods that either improve the mineral content and/or its bioavailability. ${ }^{7-9}$

Although rice is one of the most important cultivated cereals and has a significant effect on the nutritional status of the Chinese people, research on rice in China has until now been focussed mainly on yield, macronutrients such as protein and starch, and sensory quality.

Brown rice is the raw material for several ricederived products like white rice, germinated rice, and rice noodles. Therefore, in this study we concentrated on brown rice and its potential to serve as a raw material for further processing, as a first requirement to improve mineral availability.

The objectives of this paper are (1) to investigate the variation of content of $\mathrm{PA}, \mathrm{Fe}$ and $\mathrm{Zn}$ in selected Chinese rice varieties and (2) to analyse the effect of variety and rice-growing region on these parameters.

\section{MATERIALS AND METHODS Collection of rice samples}

Samples of 56 rice varieties (1 kg per variety) were obtained from different growing regions in China. These regions and their classification are

* Correspondence to: MJ Robert Nout, Laboratory of Food Microbiology, Bomenweg 2, 6703 HD Wageningen, the Netherlands E-mail: Rob.Nout@wur.nl

Contract/grant sponsor: Wageningen University, North-South Interdisciplinary Research and Education Fund (INREF) (Received 14 September 2005; revised version received 31 May 2006; accepted 5 June 2006)

Published online 22 December 2006; DOI: 10.1002/jsfa.2747 


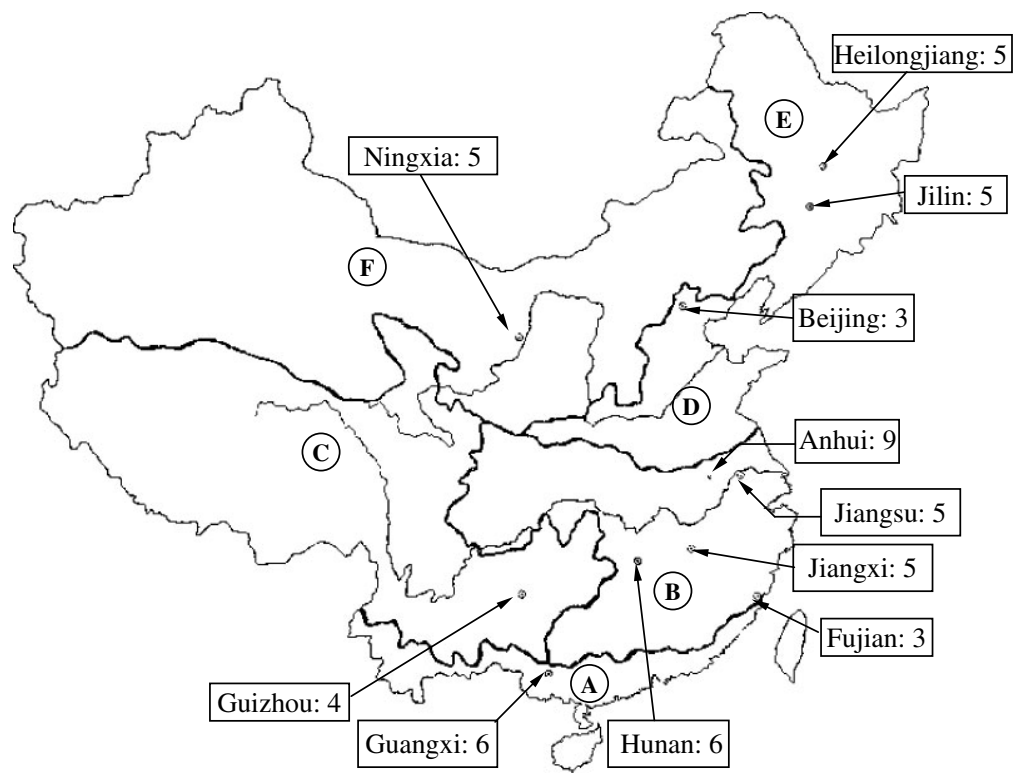

Figure 1. Rice-growing regions and locations where varieties were collected, with numbers of varieties collected.

based on climate, soil quality and agro technological infrastructure. Locations and numbers of varieties collected are shown in Fig. 1.

Currently, it is held that more than 50000 varieties of rice exist in China, of which about 230 are grown on a commercial scale. For this study, we collected 56 varieties of commercial relevance harvested in 2003 with the assistance of the Institute of Crop Germplasm Resources of the China Academic Agriculture Sciences, and the College of Agronomy and Biotechnology of the China Agricultural University.

The importance of the growing regions was a major criterion for sample collection. For example, $61.8 \%$ of the sampled varieties originate from regions $\mathrm{A}$ and $\mathrm{B}$, since these two regions occupy $78 \%$ of total planting area of the whole of China. ${ }^{10}$ Five varieties of aerobic rice (origin Anhui) were included, as well as three 'special' varieties which are used for non-staple food preparations such as porridges.

\section{Pre-treatment and processing of rice samples}

Husks were removed with a laboratory-scale dehulling machine (JLGJ45, Zhejiang, China). The resulting brown rice was ground using two different protocols, depending on the purpose. For mineral analysis, the rice was ground using a Fritsch mill (Marius Instrumenten, the Netherlands; with a $0.5 \mathrm{~mm}$ sieve). For PA analysis, samples were first dried at $70^{\circ} \mathrm{C}$ until constant weight, and were ground using a home blender (SG-280A, Shunde, China) to pass through a $1 \mathrm{~mm}$ sieve. Ground samples were sealed and stored in closed containers at $4{ }^{\circ} \mathrm{C}$ prior to analysis.

\section{Measurement of kernel dimensions}

The length and width of rice kernels were measured with a micro-ruler (accuracy: $0.01 \mathrm{~mm}$ ). For every grain, the maximum length and width were measured.
Twenty grains were measured for each variety, and the average was reported.

\section{Fe and $\mathrm{Zn}$ contents}

$\mathrm{Fe}$ and $\mathrm{Zn}$ contents were analysed with induced coupled plasma-atomic absorption spectrometry (ICPAAS) ${ }^{11}$ (ELAN 6000 spectrometer PerkinElmer, Wellesley, MA, USA). Samples were digested with $\mathrm{HNO}_{3}-\mathrm{H}_{2} \mathrm{O}_{2}-\mathrm{HF}$. Aliquots of $5.0 \mathrm{~mL}$ hydrofluoric acid and $5.0 \mathrm{~mL}$ nitric acid $(65 \% \mathrm{w} / \mathrm{w})$ were added to $0.3-0.4 \mathrm{~g}( \pm 0.001 \mathrm{~g})$ of sample and were allowed to react overnight at room temperature $\left(21^{\circ} \mathrm{C}\right)$. Then, samples were evaporated until almost dry at $120^{\circ} \mathrm{C}$. Another $5.0 \mathrm{~mL}$ nitric acid $(65 \% \mathrm{w} / \mathrm{w})$ and three times $1.0 \mathrm{~mL}$ hydrogen peroxide $\left(\mathrm{H}_{2} \mathrm{O}_{2}\right)$ were added and samples were digested in a microwave oven using a heating programme of subsequently $1 \mathrm{~min}$ at $100^{\circ} \mathrm{C}$, $5 \mathrm{~min}$ at $125^{\circ} \mathrm{C}, 5 \mathrm{~min}$ at $150^{\circ} \mathrm{C}$ and $10 \mathrm{~min}$ at $175^{\circ} \mathrm{C}$. $\mathrm{Fe}$ and $\mathrm{Zn}$ in filtered digested solutions were measured with ICP-AAS. All varieties were analysed in triplicate.

\section{Phytic acid content}

The China National Standard Analysis Method (GB/T $17406-1998)^{12,13}$ was used, based on extraction, separation on anion exchange resin, and spectrophotometric detection of the reaction product with $\mathrm{FeCl}_{3}$ and sulfosalicylic acid. All samples were analysed in triplicate.

\section{Data analysis}

Data were analysed by ANOVA and $t$-tests using the SPSS package (Sony DADC, version 12.0.1).

\section{RESULTS}

Phytic acid, iron and zinc content in rice in China Table 1 summarises $\mathrm{PA}, \mathrm{Fe}$ and $\mathrm{Zn}$ values determined in the Chinese varieties in comparison with data 
Table 1. Comparison of Fe, $\mathrm{Zn}$ and phytic acid (PA) content of Chinese brown rice with international literature data

\begin{tabular}{|c|c|c|c|c|c|c|c|}
\hline & \multirow[b]{2}{*}{$\begin{array}{c}\text { China } \\
(n=56) \\
\text { (dry mass) }\end{array}$} & \multirow[b]{2}{*}{$\begin{array}{c}\text { Vietnam } \\
(n=25)^{21} \\
\text { (fresh weight basis) }\end{array}$} & \multicolumn{2}{|c|}{ Australia ${ }^{a}$} & \multirow[b]{2}{*}{$\begin{array}{c}\text { Korea } \\
(n=68)^{26}(\text { not } \\
\text { mentioned) }\end{array}$} & \multirow[b]{2}{*}{$\begin{array}{c}\text { India } \\
(n=16)^{4} \text { (not } \\
\text { mentioned) }\end{array}$} & \multirow[b]{2}{*}{$\begin{array}{c}\operatorname{IRR}^{\mathrm{b}}(n=7)^{14} \\
\text { (fresh weight }^{\text {basis) }}\end{array}$} \\
\hline & & & $\begin{array}{c}\text { A: }(n=90)^{11} \\
\text { (at 14\% } \\
\text { moisture) }\end{array}$ & $\begin{array}{c}\text { B: }(n=22)^{27} \\
(\text { not } \\
\text { mentioned) }\end{array}$ & & & \\
\hline $\mathrm{Fe}\left(\mathrm{mg} \mathrm{kg}^{-1}\right)$ & $18.2(9.4-44.6)$ & $12.0(8.7-25.8)$ & $13(5-67)$ & $26(17-34)$ & $7.4(1.6-14)$ & $21.6(-)$ & $12.4(-)$ \\
\hline $\mathrm{Zn}\left(\mathrm{mg} \mathrm{kg}^{-1}\right)$ & $22.8(12.9-38.7)$ & $26.5(22.5-32.5)$ & $16(13-21)$ & $32(22-72)$ & $19.1(12.7-37.5)$ & $14.3(-)$ & $22.4(-)$ \\
\hline $\mathrm{PA}\left(\mathrm{g} \mathrm{kg}^{-1}\right)$ & $9.6(7.2-11.9)$ & $-{ }^{c}(-)$ & $-(-)$ & $-(-)$ & $12.6(8.6-17.6)$ & $-(-)$ & $-(-)$ \\
\hline
\end{tabular}

Results are given as the mean and the range (in parentheses).

a Two different literature data sets, labelled as $\mathrm{A}$ and $\mathrm{B}$.

b International Rice Research Institute, Philippines.

${ }^{c}$ Data not published.

obtained in other regions. In the Chinese set, the mean $\mathrm{Fe}$ content is $18 \mathrm{mg} \mathrm{kg}^{-1}$, which is lower than that found in Indian and Australian group B, but higher than Vietnamese and Korean varieties. The $\mathrm{Fe}$ content in Chinese varieties ranged from 9 to $45 \mathrm{mg} \mathrm{kg}^{-1}$. This variation is larger than that observed in the Vietnamese and Korean sets of rice samples. On the other hand, the set of Australian samples showed an even larger variation $\left(5-67 \mathrm{mg} \mathrm{kg}^{-1}\right)$. As for $\mathrm{Zn}$ content, values obtained with Chinese rice were within the range of the other reported data. In our varieties, the variation of $\mathrm{Zn}$ content is smaller than that of $\mathrm{Fe}$ content. PA contents in Chinese rice also show some variation $\left(7.2-11.9 \mathrm{~g} \mathrm{~kg}^{-1}\right)$. This variation is smaller than reported in Korean rice $\left(8.6-17.6 \mathrm{~g} \mathrm{~kg}^{-1}\right)$. PA contents in rice from other countries were not available from published literature.

The differences between our samples and those from other studies could stem from both the type of samples included in these studies and the methods of analysis used. The latter differed among the reported studies. Atomic absorbance spectrophotometry (AAS) was used for $\mathrm{Fe}$ and $\mathrm{Zn}$ analysis in the Indian varieties, while energy-dispersed X-ray was used in the IRRI study. ${ }^{14}$ Other studies (including this study) used the ICP-AAS method for mineral analysis. Procedures of pre-treatment of samples, their digestion and sensitivity limits of equipment might also affect the absolute levels of minerals reported in rice.

\section{Molar ratios of phytic acid, iron and zinc in brown rice varieties from China}

The molar ratios of $\mathrm{PA}$ to $\mathrm{Fe}$ and $\mathrm{Zn}$, and $\mathrm{Fe}$ to $\mathrm{Zn}$ are presented in Table 2. In Chinese varieties, the

Table 2. Molar Ratio of PA, Fe and $\mathrm{Zn}$ in Chinese brown rice $(n=56$ varieties)

\begin{tabular}{lccc}
\hline & $\mathrm{PA} / \mathrm{Fe}$ & $\mathrm{PA} / \mathrm{Zn}$ & $\mathrm{Fe} / \mathrm{Zn}$ \\
\hline Average & $49.5 \pm 16.0$ & $42.9 \pm 7.5$ & $0.953 \pm 0.354$ \\
Range & $15-104.8$ & $27.0-66.6$ & $0.48-2.26$ \\
Correlation & 0.12 & $0.50^{*}$ & 0.24 \\
$\quad$ between the two & & & \\
components $\left(R^{2}\right)$ & & & \\
\hline
\end{tabular}

* Significant $(P<0.01)$. mean value of molar ratios of $\mathrm{PA} / \mathrm{Fe}$ in brown rice is 50. For comparison, this value is close to the ratio in brown rice reported previously. ${ }^{15}$ This ratio is much higher than that of wheat measured in India, which was only $5.45 .{ }^{16}$ The ratios of $\mathrm{PA} / \mathrm{Fe}$ ranged from 15 to 105 , which has a large variation. These ratios, even the lowest, are much higher than required to chelate more than $90 \%$ of $\mathrm{Fe}^{17}$ According to the model of Wolters, ${ }^{15}$ the availability of $\mathrm{Fe}$ in Chinese brown rice would be $4.0-6.5 \%$ if we only take into account the effect of PA. Since brown rice also contains other complex forming substances, such as dietary fibre, and does not contain enhancers of $\mathrm{Fe}$ availability, the bioavailability of $\mathrm{Fe}$ in brown rice in China will probably be even lower.

The mean molar ratio of $\mathrm{PA}$ to $\mathrm{Zn}$ in the Chinese varieties is 42.9 , which is higher than that measured in brown rice in India. ${ }^{17}$ There is some correlation $\left(R^{2}=0.50, P<0.01\right)$ between the levels of PA and $\mathrm{Zn}$ in brown rice. Molar ratios of $\mathrm{PA}$ to $\mathrm{Zn}$ in brown rice are also different from other cereals. ${ }^{18}$ Davies and Olpin ${ }^{19}$ mentioned that regardless of the absolute levels of $\mathrm{Zn}$ and PA, the ratios of PA to $\mathrm{Zn}$ would be the major determinant of $\mathrm{Zn}$ availability. Marginal $\mathrm{Zn}$ deficiency in rats appeared at a ratio of PA to $\mathrm{Zn}$ of 10-15. Similarly, as calculated for Fe, we can predict that the availability of $\mathrm{Zn}$ in Chinese rice is $2.4-3.9 \%$, if PA is the only factor taken into account. These data suggest that molar ratio of $\mathrm{PA}$ to $\mathrm{Zn}$ in Chinese brown rice must be reduced significantly to increase bio-availability of $\mathrm{Zn}$.

The mean value of molar ratio of $\mathrm{Fe}$ to $\mathrm{Zn}$ in Chinese rice is 0.95 , which is similar to other cereals, ${ }^{18}$ although a higher ratio of 3.85 was reported elsewhere ${ }^{16}$. The mean value of molar ratio of $\mathrm{Fe}$ to $\mathrm{Zn}$ in our study is close to that of Doesthale et al. (0.80): these authors also reported that the level of $\mathrm{Fe}$ in brown rice depends significantly on the level of $\mathrm{Zn}\left(R^{2}=0.92, P<0.01\right){ }^{4}$ The latter correlation was lower in our study.

\section{Effect of the morphology of rice kernels on the content of PA, Fe and Zn}

The distribution of minerals and PA in rice kernels is not homogenous. In general, the bran contains higher levels of $\mathrm{Zn}, \mathrm{Fe}$, as well as PA. ${ }^{4}$ Since the kernel size and shape could also relate to the ratio of volume to 
Table 3. Morphology and other properties of rice varieties from China

\begin{tabular}{|c|c|c|c|c|c|c|c|c|}
\hline Variety & $\mathrm{PL}^{\mathrm{a}}$ & $\mathrm{GR}^{\mathrm{b}}$ & Length (mm) & $L / W^{C}$ & $\mathrm{TKW}^{\mathrm{d}}(\mathrm{g})$ & $\mathrm{YBR}^{\mathrm{e}}(\%)$ & $\mathrm{YWR}^{f}(\%)$ & $\mathrm{MC}^{\mathrm{g}}(\%)$ \\
\hline |l You 838 & Anhui & $\mathrm{B}$ & 6.4 & 2.5 & 19.13 & 80.2 & 70.3 & 8.1 \\
\hline Tesanai 2 & Anhui & $\mathrm{B}$ & 5.5 & 1.9 & 20.38 & 81.2 & 72.1 & 9.7 \\
\hline Xieyou 9019 & Anhui & $B$ & 7.0 & 3.0 & 20.21 & 81.4 & 70.0 & 10.4 \\
\hline Zhongxian 898 & Anhui & $\mathrm{B}$ & 7.1 & 3.1 & 21.48 & 78.9 & 69.0 & 9.4 \\
\hline Han 65 (aerobic rice) & Anhui & $\mathrm{B}$ & 5.2 & 1.8 & 16.25 & 76.8 & 58.1 & 8.4 \\
\hline Han 277 (aerobic rice) & Anhui & $\mathrm{B}$ & 5.0 & 1.7 & 17.33 & 68.2 & 61.3 & 8.7 \\
\hline Han 297 (aerobic rice) & Anhui & $\mathrm{B}$ & 5.5 & 2.0 & 19.96 & 77.0 & 69.9 & 6.6 \\
\hline Han 502 (aerobic rice) & Anhui & $\mathrm{B}$ & 6.0 & 2.0 & 21.86 & 73.7 & 66.6 & 7.6 \\
\hline Han No.9 (aerobic rice) & Anhui & $\mathrm{B}$ & 5.0 & 1.8 & 17.35 & 76.1 & 68.4 & 7.8 \\
\hline Jiamu Zaozhan & Fujian & $B$ & 7.4 & 3.5 & 20.13 & 79.7 & 68.2 & 9.8 \\
\hline Jinshanyou No. 1 & Fujian & $\mathrm{B}$ & 6.8 & 3.0 & 20.95 & 79.2 & 69.0 & 8.9 \\
\hline Weiyou 77 & Fujian & $\mathrm{B}$ & 6.7 & 2.6 & 22.19 & 80.8 & 66.5 & 8.7 \\
\hline Boyou 253 & Guangxi & $A$ & 6.0 & 2.5 & 17.58 & 74.1 & 68.4 & 7.5 \\
\hline Qiuyou 1025 & Guangxi & $A$ & 6.3 & 3.0 & 14.54 & 74.4 & 69.2 & 7 \\
\hline Qiuyougui 99 & Guangxi & $A$ & 6.6 & 3.0 & 15.93 & 73.6 & 68.6 & 9.8 \\
\hline Teyou 63 & Guangxi & $A$ & 6.3 & 2.4 & 22.41 & 70.9 & 63.4 & 7.5 \\
\hline Teyou 706 & Guangxi & $A$ & 6.4 & 2.5 & 22.35 & 77.8 & 71.5 & 7 \\
\hline Zhongyou 838 & Guangxi & $A$ & 7.1 & 3.0 & 22.34 & 74.6 & 67.1 & 8 \\
\hline Bijing 37 & Guizhou & C & 5.1 & 1.8 & 18.24 & 75.2 & 68.9 & 7 \\
\hline Jinyou 431 & Guizhou & C & 6.3 & 2.4 & 19.21 & 66.3 & 59.5 & 7 \\
\hline Jinyou 527 & Guizhou & C & 7.4 & 3.0 & 23.59 & 70.3 & 62.2 & 7.5 \\
\hline Liangyou 363 & Guizhou & C & 7 & 3.0 & 20.95 & 71.8 & 65.5 & 7 \\
\hline Fushiguang & Heilongjiang & $E$ & 5.4 & 1.8 & 21.76 & 82.2 & 72.6 & 8.5 \\
\hline Hejiang 195 & Heilongjiang & $E$ & 5.8 & 2.1 & 20.23 & 80.3 & 70.9 & 8.9 \\
\hline Xixuan No.1 & Heilongjiang & $E$ & 5.7 & 2.0 & 19.70 & 81.1 & 72.6 & 10.4 \\
\hline Wuyoudao C & Heilongjiang & $E$ & 5.6 & 2.0 & 21.55 & 81.0 & 71.9 & 9.7 \\
\hline Wuyoudao No.1 & Heilongjiang & $E$ & 5.7 & 2.0 & 18.95 & 79.2 & 70.2 & 9.7 \\
\hline Jinyou 207 & Hunan & B & 6.9 & 3.0 & 20.05 & 78.2 & 69.2 & 7.8 \\
\hline Jinyou 402 & Hunan & $B$ & 7.4 & 3.1 & 22.15 & 81.5 & 67.3 & 8.6 \\
\hline R 981 & Hunan & $\mathrm{B}$ & 6.2 & 2.5 & 18.55 & 83.6 & 75.7 & 10.7 \\
\hline V 46 & Hunan & B & 6.2 & 2.2 & 23.39 & 79.3 & 70.6 & 7.8 \\
\hline Xiangwanxian No.11 & Hunan & $\mathrm{B}$ & 6.8 & 3.1 & 19.87 & 79.1 & 68.8 & 8.8 \\
\hline XiangzaoxXian No.31 & Hunan & $B$ & 6.4 & 2.8 & 17.11 & 81.0 & 70.3 & 9.9 \\
\hline Nanjing 40 & Jiangsu & $\mathrm{B}$ & 5.2 & 1.7 & 21.15 & 84.7 & 76.2 & 7.2 \\
\hline Nanjing No.16 & Jiangsu & B & 7.3 & 3.2 & 21.18 & 74.6 & 68.8 & 7.4 \\
\hline Wuyujing No.3 & Jiangsu & $\mathrm{B}$ & 4.8 & 1.6 & 20.67 & 83.3 & 75.5 & 7.4 \\
\hline Wuyujing No.7 & Jiangsu & $\mathrm{B}$ & 5.0 & 1.6 & 20.99 & 83.5 & 76.4 & 6.6 \\
\hline Zhenjing 866 & Jiangsu & $\mathrm{B}$ & 6.7 & 2.9 & 20.30 & 75.2 & 68.9 & 6.2 \\
\hline Ganwanxian 30 & Jiangxi & B & 7.5 & 3.4 & 19.00 & 72.0 & 64.2 & 6.5 \\
\hline Ganzaoxian 49 & Jiangxi & $B$ & 7.1 & 3.3 & 18.16 & 72.0 & 64.2 & 10.4 \\
\hline Jinyou 71 & Jiangxi & $\mathrm{B}$ & 6.7 & 3.1 & 17.16 & 70.0 & 61.7 & 7.6 \\
\hline Jinyou 402 & Jiangxi & $\mathrm{B}$ & 6.7 & 3.1 & 17.38 & 72.7 & 62.5 & 7.3 \\
\hline Zhongyou 752 & Jiangxi & $\mathrm{B}$ & 6.5 & 3.4 & 15.22 & 70.2 & 62.5 & 7.5 \\
\hline Changbai No.9 & Jilin & $E$ & 5.2 & 1.7 & 21.89 & 84.8 & 76.2 & 8.9 \\
\hline Fengyou 307 & Jilin & $E$ & 5.0 & 1.8 & 18.49 & 82.6 & 74.9 & 9.6 \\
\hline Qiuguang & Jilin & $E$ & 5.2 & 1.8 & 19.26 & 83.5 & 76.1 & 8.8 \\
\hline Tong 35 & Jilin & $E$ & 5.2 & 1.8 & 20.76 & 83.1 & 74.7 & 9.5 \\
\hline Tong 95-74 & Jilin & $E$ & 4.9 & 1.7 & 19.17 & 83.2 & 75.0 & 8.8 \\
\hline Ningjing 22 & Ningxia & $\mathrm{F}$ & 5.0 & 1.7 & 19.22 & 83.3 & 74.2 & 10.6 \\
\hline Ningjing 23 & Ningxia & $F$ & 5.3 & 1.7 & 20.60 & 82.8 & 74.4 & 8.1 \\
\hline Ningjing 24 & Ningxia & $\mathrm{F}$ & 5.8 & 2.0 & 21.28 & 81.6 & 73.1 & 8.7 \\
\hline Ningjing 27 & Ningxia & $\mathrm{F}$ & 5.2 & 2.1 & 15.94 & 80.4 & 73.1 & 7.9 \\
\hline Ningjing No.5 & Ningxia & $\mathrm{F}$ & 4.9 & 1.7 & 19.21 & 81.4 & 72.1 & 9.6 \\
\hline Heinuomi $1568^{\mathrm{h}}$ & $\mathrm{i}$ & $\mathrm{D}$ & 5.2 & 2.1 & 14.88 & 66.1 & j & 7.5 \\
\hline Jupei Xiangnuo $1574^{\mathrm{h}}$ & $\mathrm{i}$ & $\mathrm{D}$ & 4.8 & 1.7 & 15.81 & 74.1 & 64.8 & 5.5 \\
\hline Tianhongmi $1571^{\mathrm{h}}$ & $\mathrm{i}$ & D & 4.6 & 1.9 & 8.13 & 67.5 & j & 7.5 \\
\hline
\end{tabular}

a Planting location.

b Growing region as shown in Fig. 1.

${ }^{c}$ Ratio of length to width.

d Thousand kernel weight (brown rice).

e Yield of brown rice from paddy.

${ }^{f}$ Yield of white rice from paddy.

$g$ Moisture content of brown rice.

${ }^{\mathrm{h}}$ Special varieties.

i Collected from the Chinese Academy of Agricultural Sciences.

j Impossible to obtain white rice from brown rice due to too small kernel size. 
surface area, we analysed the possible effect of the morphology of rice kernel on the content of minerals and PA.

The morphology of a rice kernel can be described by several parameters, such as length, width, and thousand-kernel weight (TKW). The properties of the collected samples are presented in Table 3. According to the Industrial Standard of the Ministry of China Agriculture, ${ }^{20}$ rice kernel length can be distinguished into three groups. These are long $(>6.5 \mathrm{~mm})$, medium $(5.5-6.5 \mathrm{~mm})$ and short grains $(<5.5 \mathrm{~mm})$. Indica rice (in China referred to as Xian or Hsien, long grains) is dominant in the south, while japonica rice (Fing or Keng, short grains) is widely planted in the north. In addition, aromatic, glutinous and other special types of rice are appreciated, ${ }^{10}$ these are not used for milling and noodle making but for special dishes such as porridges. The rice varieties collected in this study represented the three groups by $33 \%, 29 \%$ and $38 \%$ respectively. The longest kernel was $7.5 \mathrm{~mm}$, and the shortest was $4.6 \mathrm{~mm}$. The shape of the kernel can also be characterised by the ratio of length to width. These ratios varied from 1.7 to 3.5 . The TKW of brown rice ranged from 15.2 to $23.6 \mathrm{~g}$, except for the special varieties. The yield of brown rice from paddy ranges from 66.1 to $84.8 \%$, and the yield of white rice from paddy from 58.1 to $76.2 \%$ with the exclusion of the special varieties. The moisture content of the seeds was lower than $11 \%$. This indicated that the varieties of Chinese rice differ greatly in morphology and processing properties.

$\mathrm{PA}, \mathrm{Fe}$ and $\mathrm{Zn}$ levels in brown rice did not show a significant relation with TKW. On the other hand, $\mathrm{PA}, \mathrm{Fe}$ and $\mathrm{Zn}$ levels had a significant relation with the ratio $\mathrm{TKW} / \mathrm{L}$ at the 0.05 level. This ratio is a shape factor, instead of TKW alone. So, these results further confirmed that the shape of the kernels has a significant effect on the levels of PA, Fe and $\mathrm{Zn}$ in brown rice. We also observed a slight correlation between length, $x$, in millimetres, of brown rice kernels and yield factors, $Y$, in $\%$, as follows:

$$
\begin{gathered}
Y_{\text {brown }}=-2.5225 x+93.143\left(R^{2}=0.202\right) \\
Y_{\text {white }}=-2.8043 x+86.25\left(R^{2}=0.2644\right)
\end{gathered}
$$

where $Y_{\text {brown }}$ and $Y_{\text {white }}$ are the yields of brown and white rice, respectively.

The relation of $\mathrm{PA}, \mathrm{Fe}$ and $\mathrm{Zn}$ levels with the kernel length is presented in Table 4 and shows that the mean value of PA content tends to increase with kernel length, although not statistically significant. Notwithstanding this, PA contents related significantly $(P<0.05)$ with the ratio kernel length/width $(L / W)$ which were shown in Table 3 . At $L / W<2$, the mean value of PA was 9.1, whereas $L / W>2$ had a mean PA value of 9.9 .

Table 4 also demonstrates the wide variation of $\mathrm{Fe}$ content in Chinese rice. It appears that the variability in the short-grain rice is slightly lower than in the other groups.

The mean value of $\mathrm{Zn}$ levels in brown rice of different kernel lengths (Table 4) reveal average $\mathrm{Zn}$ contents of short-, medium- and long-grain rice to be $20.3,22.8$, and $24.6 \mathrm{mg} \mathrm{kg}^{-1}$, respectively. The mean levels differ significantly $(P<0.05)$. The $\mathrm{Zn}$ content is also correlated with kernel length and $L / W$ ratio $(P<0.01)$.

\begin{tabular}{|c|c|c|c|c|c|c|c|c|}
\hline $\begin{array}{l}\text { Kernel } \\
\text { shape }\end{array}$ & $\begin{array}{l}\text { Length } \\
\text { (mm) }\end{array}$ & $\begin{array}{l}\text { Range of } \\
\text { length } \\
(\mathrm{mm})\end{array}$ & $\begin{array}{c}\text { PA content } \\
\left(\mathrm{g} \mathrm{kg}^{-1}\right)^{*}\end{array}$ & $\begin{array}{c}\text { Range of } \\
\text { PA content } \\
\left(\mathrm{g} \mathrm{kg}^{-1}\right)\end{array}$ & $\begin{array}{l}\text { Fe content } \\
\left(\mathrm{mg} \mathrm{kg}^{-1}\right)^{*}\end{array}$ & $\begin{array}{l}\text { Range of } \\
\text { Fe content } \\
\left(\mathrm{mg} \mathrm{kg}^{-1}\right)\end{array}$ & $\begin{array}{l}\text { Zn content } \\
\left(\mathrm{mg} \mathrm{kg}^{-1}\right)^{*}\end{array}$ & $\begin{array}{c}\text { Range of } \\
\text { Zn content } \\
\left(\mathrm{mg} \mathrm{kg}^{-1}\right)\end{array}$ \\
\hline Short-grain & $5.1 \pm 0.2$ & $4.9-5.4$ & $9.2 \pm 1.2^{a}$ & $7.2-11.9$ & $16.0 \pm 4.4^{a}$ & $9.4-24.6$ & $20.3 \pm 4.0^{a}$ & $12.9-27.1$ \\
\hline Medium-grain & $6.1 \pm 0.3$ & $5.6-6.5$ & $9.7 \pm 0.9^{a}$ & $8.3-11.5$ & $19.7 \pm 7.9^{a}$ & $12.3-44.6$ & $22.8 \pm 3.8^{b}$ & $15.8-28.6$ \\
\hline Long-grain & $7.0 \pm 0.3$ & $6.7-7.4$ & $9.9 \pm 1.4^{\mathrm{a}}$ & $7.1-11.7$ & $19.2 \pm 7.2^{\mathrm{a}}$ & $9.5-40.0$ & $24.6 \pm 3.4^{c}$ & $17.1-31.3$ \\
\hline
\end{tabular}

Table 4. Phytic acid, iron and zinc in short-, medium- and long-grain rice

* Different characters in same column indicate significant differences $(P<0.05)$.

\begin{tabular}{|c|c|c|c|c|}
\hline $\begin{array}{l}\text { Growing } \\
\text { regiona }\end{array}$ & Major soil types & $\begin{array}{l}\text { Average rainfall in } \\
\text { growing period (mm) }\end{array}$ & $\begin{array}{c}\text { Average temperature } \\
\text { (cumulative temperature) }\left({ }^{\circ} \mathrm{C}\right)\end{array}$ & $\begin{array}{l}\text { Cumulative sunshine in } \\
\text { growing seasons (h) }\end{array}$ \\
\hline A & $\begin{array}{l}\text { Lateritic red soil, red earths, } \\
\text { humid-thermo-ferralitic soils }\end{array}$ & $700-1200$ & $\geq 10(5800-9300)$ & $1000-1800$ \\
\hline$B$ & Lateritic red soil, yellow-cinnamon soils & $700-1600$ & $\geq 10(4500-6500)$ & $700-1500$ \\
\hline $\mathrm{C}^{\mathrm{b}}$ & $\begin{array}{l}\text { Yellow earth, yellow-brown earths, purplish } \\
\text { soils, torrid red soils }\end{array}$ & $500-1400$ & $\geq 10(2900-8000)$ & $800-1500$ \\
\hline $\mathrm{D}$ & Solonetzs, lime concretion black soils & $580-1000$ & $\geq 10(4000-5000)$ & $2000-3000$ \\
\hline$E$ & Chernozems, meadow soils & $350-1100$ & $\geq 10(2000-3700)$ & $2200-3100$ \\
\hline$F$ & $\begin{array}{l}\text { Grey desert soils, meadow soils, cumulated } \\
\text { irrigated soils }\end{array}$ & $50-600$ & $\geq 10(2000-4250)$ & $2500-3400$ \\
\hline
\end{tabular}

Table 5. Natural conditions in major rice growing regions of China ${ }^{24}$

\footnotetext{
a See Fig. 1 for explanation of growing regions.

${ }^{b}$ Altitude of this region is $160-2700 \mathrm{~m}$; the other regions are lower altitudes.
} 
Table 6. Phytic acid (PA), Fe and Zn content in brown rice according to growing regions (mean \pm standard deviation)

\begin{tabular}{|c|c|c|c|c|c|}
\hline Growing region & Locations & Varieties $(n)$ & $\mathrm{PA}\left(\mathrm{g} \mathrm{kg}^{-1}\right)^{*}$ & $\mathrm{Fe}\left(\mathrm{mg} \mathrm{kg}^{-1}\right)^{*}$ & $\mathrm{Zn}\left(\mathrm{mg} \mathrm{kg}^{-1}\right)^{*}$ \\
\hline A & Guangxi & 6 & $9.2 \pm 0.6^{a}$ & $19.6 \pm 12.3^{a}$ & $22.6 \pm 1.1^{a}$ \\
\hline$B$ & Anhui & 9 & $9.4 \pm 1.8^{a}$ & $17.9 \pm 6.1^{\mathrm{a}}$ & $21.9 \pm 5.2^{a}$ \\
\hline$B$ & Fujian & 3 & $10.8 \pm 0.5^{b}$ & $14.2 \pm 0.1^{b}$ & $24.3 \pm 2.4^{a}$ \\
\hline$B$ & Hunan & 6 & $10.2 \pm 0.8^{b}$ & $18.3 \pm 2.4^{a}$ & $26.1 \pm 2.7^{a}$ \\
\hline$B$ & Jiangsu & 5 & $9.5 \pm 0.8^{a}$ & $14.7 \pm 2.7^{b}$ & $22.6 \pm 3.1^{a}$ \\
\hline$B$ & Jiangxi & 5 & $9.2 \pm 1.7^{\mathrm{a}}$ & $25.2 \pm 8.9^{c}$ & $25.7 \pm 3.6^{a}$ \\
\hline C & Guizhou & 4 & $9.6 \pm 1.3^{b}$ & $19.3 \pm 5.4^{a}$ & $18.6 \pm 2.6^{b}$ \\
\hline$D$ & Special varieties & 3 & $11.24 \pm 0.8^{C}$ & $16.5 \pm 2.2^{a}$ & $28.1 \pm 1.7^{\mathrm{C}}$ \\
\hline$E$ & Heilongjiang & 5 & $9.9 \pm 0.4^{b}$ & $19.9 \pm 6.4^{a}$ & $22.6 \pm 4.6^{a}$ \\
\hline$E$ & Jilin & 5 & $8.5 \pm 0.6^{d}$ & $14.5 \pm 6.2^{b}$ & $17.7 \pm 1.9^{b}$ \\
\hline \multirow[t]{2}{*}{$\mathrm{F}$} & Ningxia & 5 & $9.2 \pm 0.5^{a}$ & $17.2 \pm 3.2^{\mathrm{a}}$ & $19.7 \pm 2.4^{b}$ \\
\hline & Total/Mean & 56 & $9.58 \pm 1.2^{b}$ & $18.13 \pm 6.6^{a}$ & $22.55 \pm 4.2^{a}$ \\
\hline
\end{tabular}

* Different characters in same column indicate significant differences $(P<0.05)$.

\section{Effect of growing regions on the content of PA, Fe and $\mathrm{Zn}$}

It may be expected that the growing environment, ${ }^{21}$ location and agricultural practice will influence mineral levels in rice. There are six rice-growing regions in China with different natural conditions and agrotechnological infrastructure. Table 5 presents some characteristics on soil types, rainfall, temperature and sunshine of the growing regions. Table 6 shows the differences of $\mathrm{PA}, \mathrm{Fe}$ and $\mathrm{Zn}$ levels in rice from different growing regions. If all samples are taken into account, the growing regions did not have a significant effect $(P<0.05)$ on the PA and $\mathrm{Fe}$ levels. However, when comparing locations pair-wise by the $t$-test, we could distinguish $(P<$ $0.05)$ groups with low, medium, and higher PA content. In particular, the special varieties have higher PA, and rice grown in Jilin had significantly lower PA levels. The level of $\mathrm{Fe}$ was significantly $(P<0.05)$ higher in the rice cultivated in Jiangxi, and lower in Fujian, Jiangsu and Jilin. $\mathrm{Zn}$ content in the rice from different growing regions was significantly different $(P<0.05)$. In particular, the special varieties had higher, and rice cultivated in Jilin, Guizhou and Ningxia had lower Zn levels than elsewhere.

The mean of PA content of aerobic rice varieties, cultivated in Anhui, was $7.93 \mathrm{~g} \mathrm{~kg}^{-1}$ and differed significantly $(P<0.05)$ from those of irrigated varieties $\left(11.09 \mathrm{~g} \mathrm{~kg}^{-1}\right)$ in the same location. Mean values of $\mathrm{Fe}$ and $\mathrm{Zn}$ in aerobic rice were 17.15 and $19.46 \mathrm{mg} \mathrm{kg}^{-1}$, and 22.05 and $25.69 \mathrm{mg} \mathrm{kg}^{-1}$, respectively, for irrigated varieties which were not statistically significant.

\section{DISCUSSION}

We conclude that the levels of $\mathrm{Fe}, \mathrm{Zn}$ and PA in Chinese varieties are very diverse. This can be explained by the genetic characteristics of varieties, ${ }^{22}$ the different soil and climatic properties as were shown in Table 5, agricultural practices (such as irrigation and fertilisation), post-harvest conditions and handling. ${ }^{3,21}$ Cultivation practice and variety both influence the seed morphology, and may also affect the levels of minerals mostly occurring in chelated form with PA. ${ }^{23}$ This would suggest that there is scope for improvement of mineral content by selecting optimum varieties for specific regions. The big effect of agricultural practice is exemplified by the two groups of Australian rice that had been grown under different conditions: group A had been collected from farmers, ${ }^{11}$ while group B had been cultivated in experimental plots. ${ }^{14}$ Chinese rice cultivation conditions are diverse: of the six rice-growing regions (Fig. 1), regions $\mathrm{A}$ and $\mathrm{B}$ are dual-planting areas, region $\mathrm{C}$ is a dual-harvesting area, and the other three are single-season harvesting areas. Except for differences in planting and harvesting times, irrigation systems in these regions are also different. These differences may be expected to result in different properties of the seeds. ${ }^{24}$ Because of the variations of soil and climatic conditions within growing regions, no firm conclusion may be drawn yet concerning the regional effect on PA levels. However, it appears that $\mathrm{Fe}$ contents are related to soil types, considering the different $\mathrm{Fe}$ levels in rice from region B. More agronomical research will be required to link environmental and agro-technological factors to processing characteristics of rice and its macro- and micro-nutrients.

\section{Nutritional aspects}

The intake of $\mathrm{Fe}$ and $\mathrm{Zn}$ from rice will contribute about $12-75 \%$ and $20-81 \%$ of RDIs for adult Chinese if we calculated on the basis of the recommendation of the Chinese Nutrition Society. ${ }^{25}$ Regarding these percentages, three important aspects should be noted. First, the percentages of RDI were based on the consumption of brown rice, although Chinese people seldom consume brown rice in daily life. Second, an important amount $(54-66 \%)$ of minerals is lost as a result of milling and polishing. ${ }^{14}$ This indicates that the estimated contribution to RDI is over-optimistic and that although some rice varieties could provide most of RDIs of $\mathrm{Fe}$ and $\mathrm{Zn}$ for Chinese, there 
actually is still a big problem of $\mathrm{Fe}$ and $\mathrm{Zn}$ deficiency. Third, bio-availability of $\mathrm{Fe}$ and $\mathrm{Zn}$ in brown rice is much lower than recommended for the diet. ${ }^{25}$ This implies that there is a need to minimise mineral losses during milling and polishing and to maximise the bio-availability of minerals by dephytinisation.

\section{CONCLUSION}

From this study we conclude that the levels of $\mathrm{Fe}$ and $\mathrm{Zn}$ in Chinese rice are very diverse. This is both due to varietal and environmental effects. In principle, brown rice has the potential to provide an adequate intake of $\mathrm{Fe}$ and $\mathrm{Zn}$. However, the bio-availability of $\mathrm{Fe}$ and $\mathrm{Zn}$ is very low because of the presence of phytic acid, even in rice varieties with the lowest PA levels and highest levels of $\mathrm{Fe}$ and $\mathrm{Zn}$. With white rice, the situation is even worse, since $70-80 \%$ of minerals may be lost with the bran during milling.

Our study suggests that improving bio-availability by optimising the combination of variety and growing conditions in terms of high $\mathrm{Fe}$ and $\mathrm{Zn}$ and low PA, will only have limited effect. Such procedures will have to be combined with post-harvest processing methods that retain essential minerals on the one hand and increase their bio-availability.

\section{ACKNOWLEDGEMENT}

Financial support was provided by Wageningen University through the North-South Interdisciplinary Research and Education Fund (INREF). We gratefully acknowledge Professor Wang Huaqi from the College of Agronomy and Biotechnology of the China Agricultural University who provided several rice varieties. We also gratefully acknowledge the assistance of Birgit Hasenack with in vitro digestions, and of Dr Dick Vreugdenhil and Diaan Jamar with HPLC analysis.

\section{REFERENCES}

1 Juliano BO, Rice Products in Asia, vol 38. Regional Office for Asia and the Pacific, Laguna, Philippines, pp. 1-42 (1997).

2 FAOstat data [Online] Rice, Paddy production (Mt) China year (2004). Available: http://faostat.fao.org/[June 2005].

3 Kennedy G, Burlingame B and Nguyen VN, Nutritional contribution of rice and impact of biotechnology and biodiversity in rice-consuming countries, in Proceeding of the 20th Session of the International Rice Commission, ed. by Dat VT. Food and Agriculture Organization of the United Nations, Bangkok, Thailand, pp. 59-69 (2002).

4 Doesthale YG, Devara S, Rao S and Belavady B, Effect of milling on mineral and trace element composition of raw and parboiled rice. I Sci Food Agric 30:40-46 (1979)

5 Lucca P, Hurrell R and Potrykus I, Approaches to improving the bioavailability and level of iron in rice seeds. $\mathcal{f}$ Sci Food Agric 81:828-834 (2001).
6 Mendoza C, Effect of genetically modified low phytic acid plants on mineral absorption. Int $\mathcal{F}$ Food Sci Technol 37:759-767 (2002).

7 Gibson RS, Hotz L, Temple C, Yeudall F, Mtitimuni B and Ferguson E, Dietary strategies to combat deficiencies of iron, zinc, and vitamin A in developing countries: development, implementation, monitoring, and evaluation. Food Nutr Bull 21:219-231 (2000).

8 Lönnerdal B, Phytic acid-trace element ( $\mathrm{Zn}, \mathrm{Cu}, \mathrm{Mn}$ ) interactions. Int F Food Sci Technol 37:749-758 (2002).

9 Welch RM and Graham RD, Breeding for micronutrients in staple food crops from a human nutrition perspective. $\mathcal{F}$ Exp Bot 55:353-364 (2004).

10 IRRI. [Online]. Rice Knowledge Bank. Available: http://www. knowledgebank.irri.org/regionalsites/china [October 2004].

11 Marr KM, Batten GD and Blakeney AB, Relationships between minerals in Australian brown rice. $\mathcal{f}$ Sci Food Agric 68:285-291 (1995)

12 Ministry of Health, China Standard Analysis Method: Analysis of Phytic Acid in Food. GB/T 17 406-1998, Beijing (1998).

13 Ma GS, Jin Y, Piao J, Kok F, Bonnema G and Jacobsen E, Phytate, calcium, iron, and zinc contents and their molar ratios in foods commonly consumed in China. 7 Agric Food Chem 53:10285-10290 (2005).

14 Villareal CP, Maranville JW and Juliano BO, Nutrient content and retention during milling of brown rices from the International Rice Research Institute. Cereal Chem 68:437-439 (1991).

15 Wolters MGE, Prediction of the bioavailability of minerals and trace elements in foods. PhD thesis, Wageningen University, Wageningen (1992).

16 Grewal HK, Hira CK and Kawatra BL, Zinc, calcium and iron availability using molar ratios in processed and cooked wheat products. F Food Sci Technol 36:453-456 (1999).

17 Subba Rao K and Narasinga Rao BS, Studies on iron chelation by phytate and the influence of other mineral ions on it. Nutr Rept Int 28:771-782 (1983).

18 Grüner $M$, Horvatic $M$, Gacic $M$ and Banovíc $M$, Molar ratio of phytic acid and zinc during cereal flake production. $\mathcal{f} \mathrm{Sci}$ Food Agric 70:355-358 (1996).

19 Davies NT and Olpin SE, Studies on phytate:zinc molar contents in diets as a determination of $\mathrm{Zn}$ availability to young rats. Br F Nutr 41:591-603 (1979).

20 CHISA, Rice. China Industrial Standard (Agriculture) NY/T 593-2002 (2002).

21 Phuong TD, Chuong PV, Tong Khiemc D and Kokot S, Elemental content of Vietnamese rice. Part 1. Sampling, analysis and comparison with previous studies. Analyst 124:553-560 (1999).

22 Zimmermann $\mathrm{MB}$ and Hurrell RF, Improving iron, zinc and vitamin A nutrition through plant biotechnology. Curr Opin Biotechnol 13:142-145 (2002).

23 Otegui MS, Capp R and Staehelin LA, Developing seeds of Arabidopsis store different minerals in two types of vacuoles and in the endoplasmic reticulum. Plant Cell 14:1311-1327 (2002).

24 Zhou L, Theory and Practice of Chinese Agriculture, University of Science and Technology of China Press, Hefei (1993).

25 Chinese Nutrition Society, Chinese RDI's, China Light Industry Press, Beijing, pp. 186-209 (2003).

26 Lee H-H, Rhee H-I, Lee S-Y, Kim C-H and Choi Y-S, Contents of phytic acid and minerals of rice cultivars from Korea. f Food Sci Nutr 2:301-303 (1997).

27 Kim M, Yang H-R and Jeong Y, Mineral contents of brown and milled rice. $\mathcal{F}$ Korean Soc Food Sci Nutr 33:443-446 (2004). 